\title{
Unusual branching in the palm Euterpe edulis Mart.
}

\author{
Rita de Cássia Quitete Portela ${ }^{1,4}$, Alexandra dos Santos Pires ${ }^{2}$ and Flavio Antonio Maës dos Santos ${ }^{3}$
}

Received: 10.07.2008; accepted: 03.09.2009

ABSTRACT - (Unusual branching in the palm Euterpe edulis Mart.). The unusual development of branches along the stem of Euterpe edulis is described for the first time. Branches originated at 2 to $190 \mathrm{~cm}$ from the ground. Ramified individuals and branches were able to produce reproductive structures and some branches produced roots. A plausible cause for the observed anomaly could be genetic problems due to small population sizes. The better agreement of this process can have a positive effect in the harvest of the heart of palm through the artificial induction of sprouts, what would prevent the death of the individual.

Key words: Arecaceae, Atlantic Forest, palm heart

RESUMO - (Ramificação incomum na palmeira Euterpe edulis Mart.). O desenvolvimento anormal de ramos ao longo do estipe de Euterpe edulis é descrito pela primeira vez. Os ramos se originaram a uma altura que variou de 2 a $190 \mathrm{~cm}$ do solo. Indivíduos ramificados e ramos foram capazes de produzir estruturas reprodutivas e alguns ramos produziram raízes. Uma possível causa para a anomalia observada seriam problemas genéticos decorrentes dos pequenos tamanhos populacionais. Um melhor entendimento desse processo pode ter um efeito positivo na extração do palmito dessa espécie através da indução artificial de brotos, evitando assim a morte do indivíduo.

Palavras-chave: Arecaceae, Mata Atlântica, palmito

\section{Introduction}

The development of buds at the base of palm stems are very common, resulting in plants with clustered stems (Ridley 1907, Henderson et al. 1995). Palms with bifurcated stems, by its turn, are very unusual, occurring only in a few genus like Hyphaene and Nypa and in palms with vine-like habit (Uhl \& Dransfield 1987, Tomlinson 1990). The abnormal growth of buds along the stem, forming branches, is a rare event in other palm genus and was reported only to Syagrus cocoides (Pinheiro et al. 1996) and Socratea salazarii (Pintaud \& Millan 2004).

The genus Euterpe contains seven species, mostly of them with clustered stems (Henderson et al. 1995). Euterpe edulis Mart. is an arborescent palm that occurs along the Brazilian Atlantic Coastal Forest, just reaching Argentina and Paraguay (Henderson et al. 1995). The species exhibits monopodial growth, with stems 5 to $12 \mathrm{~m}$ tall and 100 to $150 \mathrm{~mm}$ in diameter (Henderson et al. 1995). In spite of being rare, the occurrence of clustered stems in this species was already reported by some authors (e.g. Henderson 2000, Medeiros-Costa 2003). The development of branches along the stem, by its turn, was never related before in this genus (Henderson et al. 1995, Reis $\&$ Reis 2000). The favouring of multiple-stemmed individuals has been claimed as important to the cultivation of this palm species (Henderson 2000) and we believe that the same could be said about the occurrence of bifurcated stems, which is described for the first time in this study.

The palm heart of E. edulis, locally known as "palmito", is one of the most important non-timber forest products from the Brazilian Atlantic Forest, and the harvest of this species is one of the main commercial sources of heart of palm in Brazil (Fantini et al. 2000, Silva-Matos \& Bovi 2002, Fantini \& Guries 2007). As the individuals are killed to extract the palm heart, harvesting seriously endangers $E$. edulis, which is threatened also by the loss and fragmentation of its habitat (Silva-Matos \& Bovi

1. Universidade Estadual de Campinas, Programa de Pós-Graduação em Ecologia, Caixa Postal 6109, 13083-970 Campinas, SP, Brasil

2. Universidade Federal Rural do Rio de Janeiro, Departamento de Ciências Ambientais, Rodovia BR 465, Km 07, 23890-000 Seropédica, RJ

3. Universidade Estadual de Campinas, Instituto de Biologia, Departamento de Botânica, Caixa Postal 6109, 13083-970 Campinas, SP, Brasil

4. Corresponding author: rita@quiteteportela.com.br 
2002). In spite of the increase in the production of palm heart from others species like Euterpe oleracea (Bovi \& Castro 1993) and Bactris gasipaes (Bovi 2000) the illegal harvesting of E. edulis remains due to the preference for its appearance and tasting (Reis \& Reis 2000). Illegal harvesting has lead to a decrease in the population densities of E. edulis in the Brazilian Atlantic Forest (e.g. Nodari et al. 1987, Galetti \& Aleixo 1998, Pires 2006), where it is important to many frugivores (Galetti \& Fernandez 1998, Freckleton et al. 2003). Considering this, if one is able to produce commercially E. edulis palm heart without killing the individual, not only production can be increased, but also the pressure on the natural populations of this species can be reduced. Consequently, a better knowledge of the individuals that are able to produce branches can have positive effects both for the economical use and for the conservation of E.edulis. Aiming to contribute to this question we described some morphological aspects of the individuals showing this anomaly, and discuss possible causes of this phenomenon.

\section{Material and methods}

During a study on the effects of Atlantic Forest fragmentation on E. edulis population dynamics (Portela 2008), started in June 2005, individuals with branches along the stem were found in three of the five fragments studied in Rio de Janeiro state, south-eastern Brazil. The regional climate is classified as Walter and Lieth's Equatorial type (Walter 1971). Rainfall is well distributed throughout the year (average annual rainfall of 2,092 mm, 19871997 period), with a less-rainy period extending from May to August (Souza et al. 2000). The two largest fragments, with areas of 6,500 and 3,400 ha respectively, were the Biological Reserves Poço das Antas (23K0778840, UTM7505080) and União (23K0803350, UTM7515630), the largest remnants of the threatened lowland Atlantic Forest in the state. The others fragments had areas of 19,21 and 57 ha and were located in private farms named Afetiva (23K0760400, UTM7495000), Estreito (23K0761800, UTM7496430) and Santa Helena (23K0773000, UTM7506250), respectively. The distance among fragments ranged from ca. 1 to $30 \mathrm{~km}$.

At each site we searched for all E. edulis individuals occurring in nine plots $(30 \times 30 \mathrm{~m}$ each $)$, resulting in 0.81 ha sampled in each fragment. Blocks of three plots were spaced $100 \mathrm{~m}$ from each other; within each block the distance among plots was 50 $\mathrm{m}$. Within sampling plots, one individual showing bifurcated stem was found in Poço das Antas, another one in Afetiva and a third one in Santa Helena. Additional individuals with ramifying stems were observed outside plots in the two first sites. At Estreito and União no individuals with branches was observed either inside or outside plots.

Measurements were taken from eight individuals (the three found inside plots and five additional ones from Poço das Antas). For each live stem, diameter at ground level (DGL) was measured just above the roots. Height to the highest expanded leaf was measured with a rope for palms up to $2.5 \mathrm{~m}$; for higher ones it was estimated. The total number of leaves was recorded only for non reproductive individuals (palms without signs of current or previous reproductive events), as adults were generally higher which avoided the complete view of the crown. The occurrence of flowering or fruiting was also registered. For each live branch the following measurements were taken: diameter at the base closer from stem, height, number of leaves, and the distance from the point of insertion in the stem to the ground.

\section{Results and Discussion}

The proportion of branching individuals was low in all sites, ranging from $0.22 \%$ at Poço das Antas (one of the 437 individuals sampled inside plots) to $1.47 \%$ at Afetiva (one from 68 ). Two of the six branching individuals measured at Poço das Antas were caespitose. One of them had 21 stems, six with branches (stems 6 to 11 in table 1). The second one had three stems and just one had branches (stem 3 in table 1). From the 13 branched steams sampled, four were dead. The diameter at ground level (DGL) of the nine alive stems ranged from 31.06 to $128.05 \mathrm{~mm}$ (table 1). The number of branches per stem ranged from one up to 12 . Out of 60 observed branches, 17 were dead. Branches were located since near the base of the stem until $190 \mathrm{~cm}$ from the ground (table 1). Some branches may bifurcate again until produce third order branches (table 1, see stems 5 and 10). Branches originated directly from nodes (figure 1A) and developed as juvenile individuals (figure 1B). Branches with diameter at the base up to $1 \mathrm{~cm}$ had palmate leaves, whereas larger individuals had pinnate ones. Sometimes two different branches originated from a same point in the stem (figure 1C); this was observed three times in one individual and once more in another (table 1). 
Table 1. Characteristics of Euterpe edulis showing ramified stems at three Atlantic Forest fragments in south-eastern Brazil. Stems from one to 11 were situated at Poço das Antas, the 12 at Afetiva and the 13 at Santa Helena. Stems from six to 11 pertain to a single multistemmed individual. All individuals had pinnate leaves, except the written ones as palmate leaves. Branches with the same letter were originated from a same point in the main stem. DGL = Diameter at ground level; $\mathrm{RS}=$ sprout showing roots.

\begin{tabular}{|c|c|c|c|c|c|c|c|c|c|}
\hline & \multicolumn{4}{|c|}{ Stems/Ramified Branches } & \multicolumn{4}{|c|}{ Branches } & \multirow[b]{2}{*}{ Observations } \\
\hline & $\begin{array}{l}\text { DGL } \\
(\mathrm{mm})\end{array}$ & $\begin{array}{l}\text { Height } \\
(\mathrm{cm})\end{array}$ & $\begin{array}{c}\text { Number of } \\
\text { leaves }\end{array}$ & $\begin{array}{c}\text { Number of } \\
\text { branches }\end{array}$ & $\begin{array}{l}\text { Distance from } \\
\text { soil }(\mathrm{cm})\end{array}$ & $\begin{array}{c}\text { Diameter at } \\
\text { insertion }(\mathrm{mm})\end{array}$ & $\begin{array}{l}\text { Height } \\
(\mathrm{cm})\end{array}$ & $\begin{array}{c}\text { Number of } \\
\text { leaves }\end{array}$ & \\
\hline 1 & 108.08 & 500 & 11 & 1 & 97 & 37.45 & 26.5 & 6 & - \\
\hline \multirow{3}{*}{2} & \multirow{3}{*}{128.05} & \multirow{3}{*}{600} & \multirow{3}{*}{12} & 1 & 80 & dead & - & - & $\mathrm{RS}$ \\
\hline & & & & 2 & 30 & 76 & 37 & 5 & $\mathrm{RS}$ \\
\hline & & & & 1 & 5 & 63.10 & 38.5 & 5 & RS \\
\hline \multirow[t]{7}{*}{3} & \multirow[t]{6}{*}{98.25} & \multirow[t]{6}{*}{400} & \multirow[t]{6}{*}{12} & 2 & 13 & 50.98 & 13 & 6 & RS \\
\hline & & & & 3 & 20 & 24.55 & 6.5 & 2 & - \\
\hline & & & & 1 & 20.5 & 4.37 & 0 & 1 palmate & - \\
\hline & & & & 2 & 22 & 8.99 & 0 & 3 & - \\
\hline & & & & 3 & 24 & 11.80 & 0 & 2 & - \\
\hline & & & & 4 & 24 & 45.10 & 2 & 5 & - \\
\hline & \multirow{11}{*}{96.67} & \multirow{11}{*}{91} & \multirow{11}{*}{8} & 5 & 28 & 23.07 & 1.5 & 3 & - \\
\hline \multirow{10}{*}{4} & & & & 6 & 29 & - & 0 & 24 palmate & - \\
\hline & & & & 7 & 36 & 3.22 & 0 & 1 palmate & - \\
\hline & & & & 8 & 37.5 & 8.52 & 0 & 1 & - \\
\hline & & & & 9 & 38 & 5.21 & 0 & 1 & - \\
\hline & & & & 10 & 39 & 10.37 & 0 & 1 & - \\
\hline & & & & 1 & 7.5 & 25.59 & 4 & 3 & - \\
\hline & & & & 2 & 7.5 & 56.95 & 5.5 & 5 & With 7 branches \\
\hline & & & & 3 & 11 & dead & - & - & - \\
\hline & & & & 4 & 53 & dead & - & - & - \\
\hline & & & & 5 & $58 \mathrm{a}$ & 21.42 & 3 & 1 & - \\
\hline \multirow{10}{*}{5} & \multirow{14}{*}{65.31} & \multirow{14}{*}{227} & & 6 & $59 \mathrm{a}$ & 27.43 & 3 & 1 & - \\
\hline & & & 7 & 7 & $66 \mathrm{~b}$ & 23.27 & 3 & 2 & - \\
\hline & & & & 8 & $68 \mathrm{~b}$ & 25.34 & 3.5 & 3 & - \\
\hline & & & & 9 & $77 \mathrm{c}$ & 22.73 & 2 & 1 & - \\
\hline & & & & 10 & $77 \mathrm{c}$ & dead & - & - & - \\
\hline & & & & 11 & 128 & 20.63 & 0 & 1 & - \\
\hline & & & & 12 & 132.5 & dead & - & - & - \\
\hline & & & & 1 & 6 & 17.82 & 1 & 1 & - \\
\hline & & & & 2 & 7.5 & 14.72 & 1 & 2 & - \\
\hline & & & & 3 & 11 & dead & - & - & - \\
\hline 5 branch 2 & & & & 4 & 12 & 25.71 & 0 & 1 & - \\
\hline & & & & 5 & 15 & dead & - & - & - \\
\hline & & & & 6 & 16 & dead & - & - & - \\
\hline & & & & 7 & 23 & dead & - & - & - \\
\hline 6 & 86.25 & 600 & & 1 & 31 & dead & - & - & $\begin{array}{l}\text { Main stem } \\
\text { fruiting }\end{array}$ \\
\hline 7 & dead & & & 1 & 34 & dead & - & - & - \\
\hline 8 & dead & & & 1 & 48.5 & dead & - & - & - \\
\hline & dead & & & 2 & 50 & dead & - & - & - \\
\hline & & & & 1 & 13 & 24.88 & 3 & 2 & - \\
\hline & & & & 2 & 23 & 23.15 & $\begin{array}{l}3 \\
2\end{array}$ & 1 & - \\
\hline 9 & 70.62 & 62.5 & 8 & 3 & 29 & dead & 2 & - & - \\
\hline & & & & 4 & 39.5 & dead & - & - & - \\
\hline & & & & 5 & 40 & 24.90 & - & 2 & - \\
\hline & & & & 1 & 2 & 29.07 & 14 & 1 & - \\
\hline 10 & dead & & & 2 & $6 e$ & dead & - & - & - \\
\hline & & & & 3 & $6 e$ & 40.11 & 33 & 5 & With 2 branches \\
\hline 10 branch & & & & 1 & 3.5 & 12.64 & 1 & 1palmate & - \\
\hline 3 & & & & 2 & 31.5 & 16.49 & 1 & 1 & - \\
\hline 11 & 31.06 & 24 & 6 & 1 & 8.5 & 10.1 & 0.5 & 1 palmate & - \\
\hline 11 & 31.00 & 24 & 0 & 2 & 32 & dead & - & - & - \\
\hline
\end{tabular}




\begin{tabular}{|c|c|c|c|c|c|c|c|c|c|}
\hline & \multicolumn{4}{|c|}{ Stems/Ramified Branches } & \multicolumn{4}{|c|}{ Branches } & \multirow[b]{2}{*}{ Observations } \\
\hline & $\begin{array}{l}\text { DGL } \\
(\mathrm{mm})\end{array}$ & $\begin{array}{l}\text { Height } \\
(\mathrm{cm})\end{array}$ & $\begin{array}{c}\text { Number of } \\
\text { leaves }\end{array}$ & $\begin{array}{c}\text { Number of } \\
\text { branches }\end{array}$ & $\begin{array}{l}\text { Distance from } \\
\text { soil }(\mathrm{cm})\end{array}$ & $\begin{array}{c}\text { Diameter at } \\
\text { insertion }(\mathrm{mm})\end{array}$ & $\begin{array}{l}\text { Height } \\
(\mathrm{cm})\end{array}$ & $\begin{array}{c}\text { Number of } \\
\text { leaves }\end{array}$ & \\
\hline \multirow{8}{*}{12} & \multirow{8}{*}{ dead } & & & 1 & 34 & 99.05 & 600 & - & Branch flowering \\
\hline & & & & 2 & 60 & 68.48 & 500 & 6 & - \\
\hline & & & & 3 & 87 & 29.60 & 15 & 6 & - \\
\hline & & & & 4 & 95 & 41.14 & 142 & 8 & - \\
\hline & & & & 5 & 147 & 17.24 & 0 & 2 & - \\
\hline & & & & 6 & 147 & 39.10 & 14 & 6 & - \\
\hline & & & & 7 & 163 & 39.24 & 21 & 7 & - \\
\hline & & & & 8 & 190 & 24.93 & 5 & 4 & - \\
\hline 13 & 89.57 & 400 & 9 & 1 & 187 & 31.04 & 8 & 5 & - \\
\hline
\end{tabular}

Branched individuals were able to reproduce sexually, as one of the measured stems was fruiting and another one had signals of past reproductive events. Branches can also produce inflorescences while attached to the stem.

The development of roots was observed in five branches with diameter at the point of insertion larger than $5 \mathrm{~cm}$ (table 1). Roots originated around the base of the branches, acquiring a conic shape and growing towards the ground (figure 1D). In three of these branches - located at 5,13 and $30 \mathrm{~cm}$ heights - the roots had already reached the ground. In such cases it is possible that the branches became independent after the complete separation of the stem, as observed in caespitose palms (e.g Portela 2008). This fact, however, was not observed in the field, and do not seems possible to branches located at higher positions.

Vegetative branching by underground suckering usually characterizes multiple-stemmed palms and is a very common process of regeneration in these plants. The abnormal development of branches along palm stems, by its turn, has been commonly attributed to physiological stress and/ or damages of the apical meristem (Pinheiro et al. 1996, Henderson, unpublished data). As none of the bifurcated individuals was growing in flooded areas, the observed anomaly does not seem to be related with this kind of environmental stress. Besides that, individuals with branched stems were only a small portion of the population living in the same microclimate conditions. So, physiological stress does not seem to be the cause of branching. Considering physical damage, Rodríguez-Buriticá et al. (2005) described the development of multiple-crowns in Geonoma orbignyana individuals that survived to severe damages in the stem or the apical meristem. In our case, however, we can discard the effects of physical damages as all studied individuals were erect and without signs of injury. Others damages to the apical meristem, like insects or diseases, also did not seem to be the cause of branching as some bifurcated individuals were inclusive reproducing.

Bovi et al. (1987) studying E. edulis $\times$ E. oleracea hybrids found that $70 \%$ to $80 \%$ of them were multistemmed, but the kind of branching observed in this study had never been described by this authors. Additionally, the occurrence of E. oleracea had never been detected at the fragments studied and according to Medeiros-Costa (2003) southeastern E. edulis individuals hardly hybridized with $E$. oleracea.

Considering what were said before, a plausible cause for the observed anomaly could be genetic problems due to the small size of the populations studied. The intensive harvesting and poor incentives for investment in adequate management practices have led to the decline of E. edulis over much of the fragmented Atlantic Forest where many of the surviving populations are small (Galetti \& Fernandez 1998, Silva Matos \& Watkinson 1998). The E. edulis densities found by Pires (2006) at Poço das Antas, Afetiva and Santa Helena were respectively 664, 142 and 122 individuals/ha while in less disturbed areas densities up to 8.367 individuals/ha were found (Reis et al.2000). In populations as small as the ones studied here, a negative inbreeding effect would be expected (Ellstrand \& Elam 1993). As described above, some branches were producing roots, apparently establishing a new independent stem. This strategy may have a positive effect by increasing the size of these populations, although not their genetic variation.

\section{Acknowledgments}

The authors thanks the Brazilian Government for the financial support through CAPES (Coordenação de Aperfeiçoamento de Pessoal de Nível Superior), FAPESP (Fundação de Amparo à Pesquisa do Estado de São Paulo - 2005/60788-4 and 2001/13559-9), 

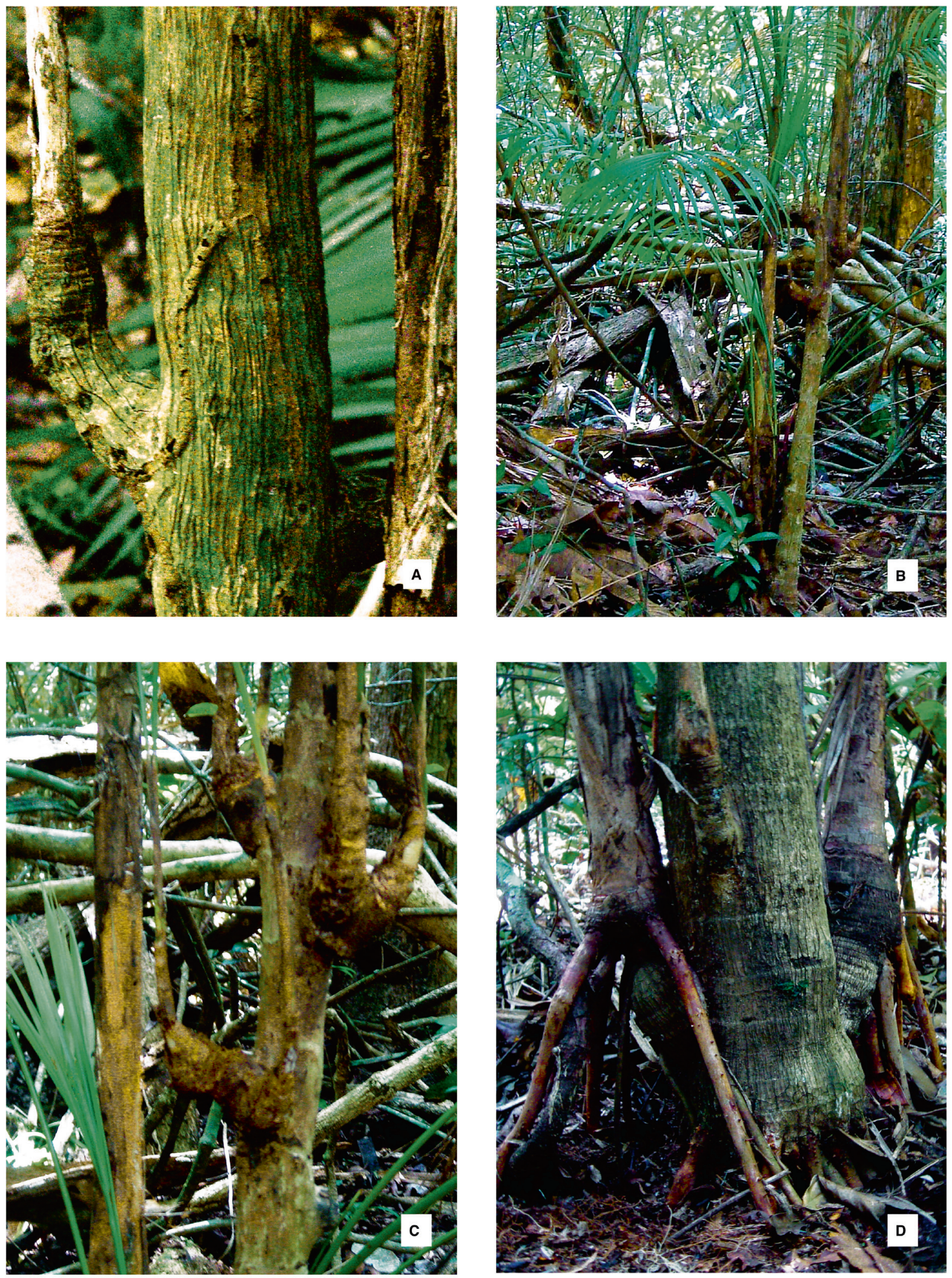

Figure 1. Morphological characteristics of Euterpe edulis individuals showing ramified stems. A. Detail of a branch originated directly from nodes. B. Juvenile showing several branches. C. Two branches originated from a same point in the stem acquiring a bifurcated aspect at the base. D. Roots around the base of the branches, with a conic shape, same of them reaching the soil. 
FAPERJ (E-26/101.069/2007) and Universidade Estadual de Campinas (FAEPEX - 1452/04); the IBAMA (Instituto Brasileiro do Meio Ambiente e Recursos Naturais Renováveis) and the farms's owners for the logistic support during field work; the Idea Wild for equipment donation; A. Henderson and H. Lorenzi for ideas and comments on earlier versions of the manuscript and Fernando Fernandez for the useful suggestions and for correcting the English.

\section{Literature cited}

Bovi, M.L.A. 2000. O agronegócio palmito de pupunha. 2000. O Agronômico 52: 10-12.

Bovi, M.L.A. \& Castro, A. 1993. Assaí. In: J.W. Clay \& C.R. Clement (eds.). Selected Species and Strategies to Enhance Income Generation from Amazonian Forests. FAO, Roma, pp. 58-67.

Bovi, M.L.A., Godoy Júnior., J. \& Sáes, L.A. 1987. Híbridos interespecíficos de palmiteiro (Euterpe oleracea x Euterpe edulis). Bragantia 46: 343-363.

Ellstrand, N.C. \& Elam, D.R. 1993. Population genetic consequences of small population size in plants: Implications for plant conservation. Annual Review of Ecology and Systematics 24: 217-42.

Fantini, A.C. \& Guries, R. 2007. Forest structure and productivity of palmiteiro (Euterpe edulis Martius) in the Brazilian Mata Atlântica. Forest Ecology and Management 242: 185-194.

Fantini, A.C., Ribeiro, R.J. \& Guries, R.P. 2000. Produção de palmito (Euterpe edulis Martius Arecaceae) na Floresta Ombrófila Densa: potencial, problemas e possíveis soluções. In: M.S. Reis \& A. Reis (eds.). Euterpe edulis Martius - Palmiteiro: Biologia, conservação e manejo. Herbário Barbosa Rodrigues, Itajaí, pp. 256-280.

Freckleton, R.P., Silva-Matos, D.M., Bovi, M.L.A. \& Watkinson, A.R. 2003. Predicting the impacts of harvesting using structured population models: the importance of density-dependence and timing of harvest for a tropical palm tree. Journal of Applied Ecology 40: 846-858.

Galetti, M. \& Aleixo, A. 1998. Effects of palm heart harvesting on avian frugivores in the Atlantic rain forest of Brazil. Journal of Applied Ecology 35: 286-293.

Galetti, M. \& Fernandez, J.C. 1998. Palm heart harvesting in the Brazilian Atlantic Forest: changes in industry structure and the illegal trade. Journal of Applied Ecology 35: 294-301

Henderson, A. 2000. The genus Euterpe in Brazil. In: M.S. Reis \& A. Reis (eds.). Euterpe edulis Martius Palmiteiro: Biologia, Conservação e Manejo. Herbário Barbosa Rodrigues, Itajaí, pp. 256-280.

Henderson, A., Galeano, G. \& Bernal, R. 1995. Field Guide to the Palms of the Americas. Princeton University Press, New Jersey.
Medeiros-Costa, J.T. 2003. Flora Fanerogâmica da Ilha do Cardoso (São Paulo, Brasil): Arecaceae (Palmae). In: M.M.R.F. Melo, F. Barros, S.A.C. Chiea, M. Kirizawa, S.L. Jung-Mendaçolli \& M.G.L. Wanderley (eds.). Flora Fanerogâmica da Ilha do Cardoso v. 10. Instituto de Botânica, São Paulo, pp. 57-75.

Nodari, R.O., Reis, A., Guerra, M.P., Reis, M.S. \& Floriano, E.P. 1987. Análise preliminar no inventário do palmiteiro em floresta ombrófila densa montana. In: Anais do Primeiro Encontro Nacional de Pesquisadores em Palmito, Curitiba, pp. 159-163.

Pinheiro, C.U.B., Balick, M.J. \& Frazão, J.M.F. 1996. Branching in Syagrus cocoides (Arecacea) in Maranhão, northeastern Brazil. Brittonia 48: 556-565.

Pintaud, J. \& Millan, B. 2004. Vegetative transformation of inflorescences in Socratea salazarii. Palms 48: 86-89.

Pires, A.S. 2006. Perda de Diversidade de Palmeiras em Fragmentos de Mata Atlântica: Padrões e Processos. Tese de Doutorado, Universidade Estadual Paulista, Rio Claro.

Portela, R.C.Q. 2008. Dinâmica de Três Espécies de Palmeiras em uma Paisagem Fragmentada no Domínio da Mata Atlântica no Estado do Rio de Janeiro. Tese de Doutorado, Universidade Estadual de Campinas, Campinas.

Reis, M.S. \& Reis, A. 2000. Euterpe edulis Martius Palmiteiro: Biologia, Conservação e Manejo. Herbário Barbosa Rodrigues, Itajaí.

Reis, M.S., Fantini, A.C., Nodari, R.O., Reis, A., Guerra, M.P. \& Mantovani, A. 2000. Management and conservation of natural populations in Atlantic Rain Forest: the case study of the palm heart (Euterpe edulis Martius). Biotropica 32: 894-902.

Rodríguez-Buriticá,S., Orjuela,M.A.\& Galeano,G. 2005. Demography and life history of Geonoma orbignyana: an understory palm used as foliage in Colombia. Forest Ecology and Management 211: 329-340.

Ridley, H.N. 1907. Branching in palms. Annals of Botany 21: 415-422.

Silva-Matos, D.M. \& Bovi, M.L.A. 2002. Understanding the threats to biological diversity in south-eastern Brazil. Biodiversity and Conservation 11: 1747-1578.

Silva-Matos, D.M. \& Watkinson, A.R. 1998. The fecundity, seed, and seedling ecology of the edible palm Euterpe edulis in southeastern Brazil. Biotropica 30: 595-603.

Souza, A.F., Martins, F.R. \& Silva-Matos, D.M. 2000. Detecting ontogenetic stages of the palm Attalea humilis Mart. ex Spreng. in fragments of the Brazilian Atlantic Forest. Canadian Journal of Botany 78: 1227-1237.

Tomlinson, P.B. 1990. The structure biology of palms. Clarendon Press, Oxford.

Uhl, N. \& Dransfield, J. 1987. Genera Palmarum. Allen Press, Lawrence.

Walter, H. 1971. Ecology of Tropical and Subtropical Vegetation. Oliver and Boyd, Edinburgh. 